\title{
RET/PTC-induced gene expression in thyroid PCCL3 cells reveals early activation of genes involved in regulation of the immune response
}

\author{
E Puxeddu 1,4, J A Knauf ${ }^{1}, M$ A Sartor ${ }^{2}$, N Mitsutake $^{1}$, E P Smith ${ }^{1}$,

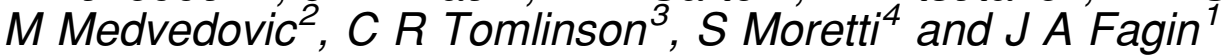

\author{
${ }^{1}$ Division of Endocrinology and Metabolism, University of Cincinnati College of Medicine, Cincinnati, Ohio 45267, USA \\ ${ }^{2}$ Center for Biostatistic Service, University of Cincinnati College of Medicine, Cincinnati, Ohio 45267, USA \\ ${ }^{3}$ Center for Environmental Genetics, University of Cincinnati College of Medicine, Cincinnati, Ohio 45267, USA \\ ${ }^{4}$ Dipartimento di Medicina Interna, Università degli Studi di Perugia, Perugia 06126, Italy
}

(Requests for offprints should be addressed to J A Fagin; Email: James.Fagin @uc.edu)

\begin{abstract}
RET/PTC rearrangements represent key genetic events involved in papillary thyroid carcinoma (PTC) initiation. The aim of the present study was to identify the early changes in gene expression induced by RET/PTC in thyroid cells. For this purpose, microarray analysis was conducted on PCCL3 cells conditionally expressing the RET/PTC3 oncogene. Gene expression profiling $48 \mathrm{~h}$ after activation of RET/PTC3 identified a statistically significant modification of expression of 270 genes. Quantitative PCR confirmation of 20 of these demonstrated $90 \%$ accuracy of the microarray. Functional clustering of genes with greater than or less than 1.75-fold expression change (86 genes) revealed RET/PTC3-induced regulation of genes with key functions in apoptosis (Ripk3, Tdga), cell-cell signaling (Cdh6, Fn1), cell cycle (II24), immune and inflammation response (Cxcl10, Scya2, II6, Gbp2, Oas1, Tap1, RT1Aw2, C2ta, Irf1, Lmp2, Psme2, Prkr), metabolism (Aldob, Ptges, Nd2, Gss, Gstt1), signal transduction (Socs3, Nf1, Jak2, Cpg21, Dusp6, Socs1, Stat1, Stat3, Cish) and transcription (Nr4a1, Junb, Hfh1, Runx1, Foxe1). Genes coding for proteins involved in the immune response and in intracellular signal transduction pathways activated by cytokines and chemokines were strongly represented, indicating a critical role of RET/PTC3 in the early modulation of the immune response.
\end{abstract}

Endocrine-Related Cancer (2005) 12 319-334

\section{Introduction}

Rearrangements of the proto-oncogene RET resulting in its constitutive activation are believed to play a causative role in the pathogenesis of a significant proportion of papillary carcinomas of the thyroid (PTC) (Santoro et al. 2002). The RET gene encodes a transmembrane tyrosine kinase (TK) receptor whose expression and function is normally restricted to a subset of cells derived from the neural crest. In thyroid follicular cells, RET activation occurs through chromosomal recombination resulting in illegitimate expression of a fusion protein consisting of the intracellular TK domain of RET coupled to the $\mathrm{N}$-terminal fragment of a heterologous gene. The promoter region of the partner gene drives constitutive expression of the chimeric gene. There are at least ten different types of $R E T / P T C$ that differ according to the $5^{\prime}$ partner gene involved in the rearrangement. RET/PTCl and $R E T / P T C 3$ are the most common types, accounting for more than $90 \%$ of all the rearrangements. The resulting fusion proteins dimerize in a ligandindependent manner and constitutively activate the TK function of RET (Durick et al. 1995, Tong et al. 1997). Several signaling pathways activated by RET/ PTC have been identified. Among these, autophosphorylation of tyrosine residues Y905, Y1015, Y1062 of the full length of RET, which form docking sites for Grb7/Grb10, PLC $\gamma$ and Shc/Snt(Frs2)/Enigma respectively (Borrello et al. 1996, Arighi et al. 1997, Durick 
et al. 1998), are required for its oncogenic function in vitro.

RET rearrangements are found in 5-40\% of PTCs in the adult population (Santoro et al. 2002). They are significantly more prevalent in pediatric PTCs, and in cancers from children exposed to radiation after the Chernobyl nuclear accident (Fugazzola et al. 1995, Bongarzone et al. 1996, Nikiforov et al. 1997). There is compelling evidence pointing to RET/PTC as a key first step in thyroid cancer pathogenesis (Ito et al. 1993, Viglietto et al. 1995, Jhiang et al. 1996, Santoro et al. 1996, Mizuno et al. 1997, Powell et al. 1998, Sugg et al. 1998, Nikiforov et al. 1999, Nikiforova et al. 2000). Moreover, recent molecular genetic studies show the consistent occurrence of mutations of genes coding for effectors signaling along the MAP kinase (MAPK) pathway in PTCs, namely rearrangements of the receptor TKs $R E T$ or $T R K$, as well as point mutations of the intracellular signaling proteins $B-R A F$ and $R A S$. Interestingly, there is little or no overlap between these genetic events in the same cancer, pointing to the requirement for activation of MAPK for thyroid cell transformation to PTC.

Relatively little is known about the events that follow $R E T / P T C$ activation and that may be associated with PTC progression. Acute RET/PTC activation stimulates both DNA synthesis and apoptosis in thyroid cells, is associated with loss of thyroid-specific differentiation, and interferes with thyrotropin (TSH) receptor-mediated intracellular signaling at various levels (Wang et al. 2003). Moreover, it triggers a rapid and vigorous induction of microsomal prostaglandin $\mathrm{E}$ synthase-1 (mPGES-1) and cyclooxygenase (COX)-2 expression and stimulation of $\mathrm{PGE}_{2}$ biosynthesis (Puxeddu et al. 2003). Very recently, thyroid cells engineered to express $R E T / P T C 3$ have also been shown to produce high amounts of monocyte chemoattractant protein 1 (MCP1) and granulocytemacrophage colony stimulating factor (GM-CSF) (Russell et al. 2003) and to express osteopontin and its receptor CD44, all of which have been implicated in the determination of the mitogenic and invasive phenotype of RET/PTC-transformed thyroid cells (Castellone et al. 2004a,b). Taken together, these data suggest that expression of RET/PTC in normal follicular cells induces significant phenotypic changes oriented towards neoplastic transformation.

The RET/PTC oncoproteins may be directly involved in inducing inflammatory responses in thyroid tissues. This hypothesis is supported by the observation that RET/PTC3-expressing thyrocytes express high levels of proinflammatory cytokines such as MCP1 and GM-CSF (Russell et al. 2003), the appearance of inflammatory cells in thyroid glands from RET/PTC1 and RET/PTC3 transgenic mice (Jhiang et al. 1996, Santoro et al. 1996, Powell et al. 1998), the rejection of transplanted RET/PTC3expressing thyroid tumors in syngeneic mice (Powell et al. 2001) and the demonstration of immunogenicity of the RET/PTC3 protein (Powell et al. 2003). This has led to speculation that RET/PTC may account for the chronic inflammatory infiltrates and foci of thyroiditis observed in $10-30 \%$ of tumor specimens of patients with PTC (Kebebew et al. 2001). Some authors report the detection of RET/PTC in non-neoplastic Hashimoto's thyroiditis (Wirtschafter et al. 1997), although this has not been confirmed by others (Nikiforov 2002). RET has recently been shown to regulate the activation and transcriptional activity of Stat1 and Stat3 (Schuringa et al. 2001, Hwang et al. 2003, Hwang et al. 2004). Stats are a family of latent transcription factors that are activated in response to many cytokines and growth factors and play critical roles in the regulation of the immune response and cellular growth. RET/PTC expression induces the phosphorylation of Stat1 at Y701, resulting in the induction of expression of interferon (IFN)-responsive genes (Hwang et al. 2004). Moreover, MEN2A-RET (Schuringa et al. 2001), a constitutive active mutant of RET causing multiple endocrine neoplasia type $2 \mathrm{~A}$, as well as RET/PTC (Hwang et al. 2003), associates with Stat3 and induce its phosphorylation and transcriptional activity (Schuringa et al. 2001). The evidence that oncogenic RET mutants regulate Stat 3 is of interest because of its role in tumorigenesis. Stat3 is upregulated in many human cancer types, protects from apoptosis and promotes cell proliferation in several cell types. In addition, Stat 3 induces the expression of genes involved in survival and proliferation (reviewed in Pedranzini et al. 2004). Moreover, Stat3 is required for development of skin tumors in the two-step model of chemically induced skin carcinogenesis (Chan et al. 2004). Stat 3 has also been shown to inhibit the immune response elicited by growing and invading tumor cells either by suppressing release of proinflammatory stimuli or by repressing the capacity of dendritic cells to sense tissue damage and the presence of inflammation (Wang et al. 2004). By contrast, Stat1 mediates primarily proinflammatory signals in part by increasing transcription from type IV IFN- $\gamma$-responsive promoters of class II transactivator genes (Hwang et al. 2004).

Here we report the results of gene expression profiling experiments performed in PCCL3 cells induced to conditionally express RET/PTC3. Two hundred and seventy genes displayed a statistically significant 

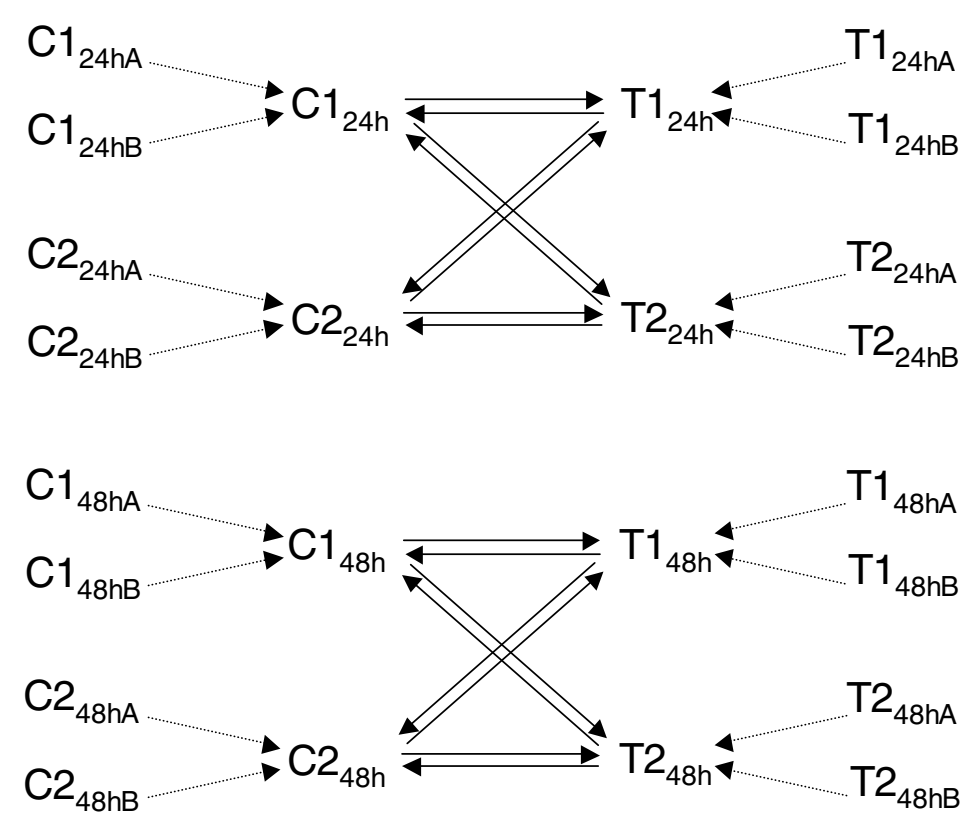

Figure 1 Design of the microarray experiment. Microarray slides were co-hybridized $(\rightarrow)$ with cDNA from PTC3-5 cells treated with $(\mathrm{T})$ or without $(\mathrm{C})$ dox for 24 or $48 \mathrm{~h}$. Each RNA sample contained the pooled (arrows with dotted lines) RNA from two plates $(\mathrm{A}$ and $\mathrm{B}$ ). For each time point, cDNA from two independent experiments was tested (1 and 2). Cross-co-hybridization (arrows at 45 degrees) between treated and control samples from two independent experiments was also performed. Every co-hybridization was repeated a second time switching the Cy3 and Cy5 dyes $(\leftarrow)$. Altogether, for each time point eight independent hybridizations were performed.

RET/PTC3-induced modification of expression. As expected, a subset of these genes represented possible mediators of RET/PTC-dependent thyrocyte transformation and others grouped into a variety of functional classes. A particularly striking subset of genes (14 out of 86 with greater than or less than 1.75 -fold change) belongs to a cluster involved in the regulation of the immune response.

\section{Experimental procedures}

\section{Cell lines and reagents}

PCCL3 cells, a clonal rat thyroid line requiring TSH for growth, were maintained in $\mathrm{H} 4$ complete medium consisting of Coon's medium/F12 high zinc supplemented with $5 \%$ fetal bovine serum, $0.3 \mathrm{mg} / \mathrm{ml}$ L-glutamine, $1 \mathrm{mIU} / \mathrm{ml} \mathrm{TSH}, 10 \mu \mathrm{g} / \mathrm{ml}$ insulin, $5 \mu \mathrm{g} / \mathrm{ml}$ apo-transferrin, $10 \mathrm{nM}$ hydrocortisone and penicillin/ streptomycin. $\mathrm{H} 3$ complete medium was identical to $\mathrm{H} 4$ complete medium but without addition of TSH. The PTC3-5 line was derived from PCCL3 cells to obtain doxycycline (dox)-inducible expression of RET/ PTC3, as described elsewhere (Wang et al. 2003).

\section{RNA isolation}

PTC3-5 cells were grown in $10 \mathrm{~cm}$ dishes until almost confluent and then preincubated with $\mathrm{H} 3$ medium for 3 days before addition of dox. After incubation with or without $1 \mu \mathrm{g} / \mathrm{ml}$ dox for the indicated time, total RNA was isolated using TRIzol reagent (Invitrogen) ( $1 \mathrm{ml}$ for a $10 \mathrm{~cm}$ dish) following the manufacturer's recommended protocol. The RNA was further purified using RNeasy Mini Kit (Qiagen) following the accompanying RNA Cleanup protocol.

\section{Microarray analysis}

Experimental design is depicted in Fig. 1. Microarray slides were spotted with a combination of a commercial rat 70-mer oligonucleotide library as well as purified PCR products of a cDNA subtractive suppression hybridization library generated from PTC3-5 cells with or without expression of RET/PTC3. The rat 70-mer oligonucleotide library, representing 4273 known genes, was obtained from Qiagen-Operon (Alameda, CA, USA). The PTC3-5 substractive suppression hybridization library was generated in our laboratory and included 364 known sequences. The construction 
of this library and the purification of the library PCR products for custom microarray generation has been described elsewhere (Puxeddu et al. 2003). The oligonucleotides and the PCR products were spotted in duplicate at $22{ }^{\circ} \mathrm{C}$ and $65 \%$ relative humidity using a high-speed robotic machine (OmniGrid model; GeneMachines, San Carlos, CA, USA) with Stealth pins (SMP 3 pins) from Telechem (Sunnyvale, CA, USA) on a mounted 48-pin head. Spot volumes were $0.5 \mathrm{nl}$ and spot diameters were $75-85 \mu \mathrm{m}$. The 70 -mer oligonucleotides and the PCR products were suspended in $3 \times \mathrm{SSC}$ at $30 \mathrm{mM}$ and $0.2-1 \mu \mathrm{g} / \mu \mathrm{l}$ respectively, and printed on aminosilane-coated UltraGAPS slides (Corning, Acton, MA, USA). The DNAs were crosslinked to the slide substrate by exposure to $600 \mathrm{~mJ}$ of ultraviolet light. For the hybridization step (DeRisi et al. 1996), the slides were placed in a hybridization station (Genomic Solutions, Inc., Ann Arbor, MI, USA) using Microarray Hybridization Buffer \#1 from Ambion (Austin, TX, USA). Details of the hybridization protocol can be found at http:// microarray.uc.edu.

The oligonucleotides on the microarray slides were co-hybridized with cDNA from PTC3-5 cells treated with or without dox for 24 or $48 \mathrm{~h}$. Each RNA sample contained the pooled RNA from two plates. For each time point, cDNA from two independent experiments was tested. Cross-co-hybridization between treated and control samples from two independent experiments was also performed. Every co-hybridization was repeated a second time switching the Cyanine- 3 and Cyanine-5 dyes (Cy3 and $\mathrm{Cy} 5$ ) (Amersham). Altogether, for each time point, eight independent hybridizations were performed (Fig. 1).

Fluorescence-labeled cDNAs were synthesized from $20 \mu \mathrm{g}$ total RNA using an indirect amino allyl labeling method (DeRisi et al. 1996). The cDNA was synthesized by an oligo(dT)-primed, reverse transcriptase reaction, and the cDNA labeled with monofunctional reactive $\mathrm{Cy} 3$ and $\mathrm{Cy} 5$ dyes. Details can be found at http://microarray.uc.edu. Imaging and data generation were carried out using a GenePix 4000A and GenePix $4000 \mathrm{~B}$ and associated software from Axon Instruments, Inc. (Foster City, CA, USA). The microarray slides were scanned with dual lasers with wavelength frequencies to excite $\mathrm{Cy} 3$ and $\mathrm{Cy} 5$ fluorescence emission. Images were captured in JPEG and TIFF files, and DNA spots captured by the adaptive circle segmentation method. Information extraction for a given spot was based on the median value for the signal pixels minus the median value for the background pixels to produce a gene set data file for all the DNA spots.

\section{Data analysis and normalization}

The data representing raw spot intensities generated by the GenePix software were analyzed to identify differentially expressed genes and characterize gene expression profiles under different experimental conditions. Data normalization was performed separately in three steps for each microarray. First, channelspecific local background intensities were subtracted from the median intensity of each channel (Cy3 and Cy5). Secondly, background-adjusted intensities were log-transformed and the differences $(\mathrm{R})$ and averages (A) of log-transformed values were calculated as $\mathrm{R}=$ $\log _{2}(\mathrm{X} 1)-\log _{2}(\mathrm{X} 2)$ and $\mathrm{A}=\left[\log _{2}(\mathrm{X} 1)+\log _{2}(\mathrm{X} 2)\right] / 2$, where $\mathrm{X} 1$ and $\mathrm{X} 2$ denote the $\mathrm{Cy} 5$ and $\mathrm{Cy} 3$ intensities of each spot after subtracting local backgrounds respectively. Thirdly, data centering was performed by fitting the array-specific local regression model of $\mathrm{R}$ as a function of A (Yang et al. 2002). The difference between the observed log-ratio and the corresponding fitted value represented the normalized logtransformed gene expression ratio. Normalized logintensities for the two channels were then calculated by adding a half of the normalized ratio to $\mathrm{A}$ for the $\mathrm{Cy} 5$ channel and subtracting half of the normalized ratio from $\mathrm{A}$ for the $\mathrm{Cy} 3$ channel.

\section{Identification of differentially expressed genes}

The statistical analysis was performed for each gene separately by fitting the following mixed effects linear model (Wolfinger et al. 2001): $\mathrm{Y}_{\mathrm{ijkl}}=\mu+\mathrm{A}_{\mathrm{i}}+\mathrm{S}_{\mathrm{j}}+$

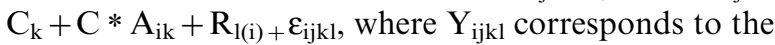
normalized log-intensity on the ith array $(i=1, \ldots, 16)$, with the $j$ th treatment-time combination $(j=1, \ldots, 4$ for control 24 and $48 \mathrm{~h}$, and treated 24 and $48 \mathrm{~h}$ respectively), labeled with the $\mathrm{kth}$ dye $(\mathrm{k}=1$ for Cy5, and 2 for $\mathrm{Cy} 3$ ), and on the 1th replicate spot of the ith array $(1(i)=1,2) . \mu$ is the overall mean log-intensity, $A_{i}$ is the effect of the ith array, $S_{j}$ is the effect of the jth treatment time and $\mathrm{C}_{\mathrm{k}}$ is the effect of the kth dye. Assumptions about model parameters were the same as described (Wolfinger et al. 2001), with array and replicate spot effects assumed to be random, and treatment and dye effects assumed to be fixed. Statistical significance of the differential expression between treatment and control at 24 and $48 \mathrm{~h}$, after adjusting for the additional effects, was assessed by calculating $P$-values for corresponding linear contrasts. Multiple hypothesis testing adjustment was performed by calculating false discovery rates (Hochberg \& Benjamini 1990, Benjamini et al. 2001). Data normalization and statistical analyses were performed using SAS statistical software package (SAS Institute, Inc., Cary, NC, USA). 


\section{Quantitative RT-PCR}

Confirmation of the microarray results was carried out by quantitative real-time PCR (QPCR) analysis. Cells were harvested at the indicated time and RNA isolated using TRIreagent as directed by the manufacturer (Molecular Research Center, Inc., Cincinnati, $\mathrm{OH}$, USA). One microgram of total RNA was reverse transcribed in a $20 \mu \mathrm{l}$ reaction containing $200 \mathrm{U}$ SuperScript III reverse transcriptase (Invitrogen), $50 \mathrm{ng}$ random primers, $500 \mu \mathrm{M}$ dNTP mix, $5 \mathrm{mM}$ dithiothreitol and $40 \mathrm{U}$ RNaseOUT (Invitrogen) for $60 \mathrm{~min}$ at $50^{\circ} \mathrm{C}$, followed by a $15 \mathrm{~min}$ heat inactivation at $70^{\circ} \mathrm{C}$. Twenty-five nanograms of the obtained cDNA were then used as a template in a PCR reaction containing $200 \mathrm{nM}$ of the primer pairs for amplification of either $\beta$-actin or the indicated gene product (Table 1). PCR amplifications were performed using the Platinum SYBR Green qPCR SuperMix UDG as directed by the manufacturer (Invitrogen). The amplification conditions were optimized for the PerkinElmer Life Sciences ABI 5700 instrument (Applied Biosystems, Foster City, CA, USA) and assays were run in triplicate under the following conditions: Platinum Taq polymerase activation, $50^{\circ} \mathrm{C}$ for $2 \mathrm{~min}$ followed by $95^{\circ} \mathrm{C}$ for $2 \mathrm{~min}$; PCR, 50 cycles of $95^{\circ} \mathrm{C}, 15 \mathrm{~s}$ and $60^{\circ} \mathrm{C}, 30 \mathrm{~s}$. PCR products were demonstrated to be a single PCR product by melting curve and electrophoretic analysis. To avoid potential problems from contaminating genomic DNA, PCR primers were designed to span introns whose location was determined by blasting each rat cDNA sequence of interest against the NCBI rat genome database. This was further verified by the absence of signal when reactions were performed without reverse transcriptase. The cycle threshold (CT) value coupled with individualized amplification efficiencies for each primer set was used to calculate the normalized expression of the indicated gene mRNA using the Q-Gene program (Muller et al. 2002).

\section{Functional clustering}

Differentially expressed genes were clustered in 12 functional categories based on the 'Biological Process' principle of the GeneOntology Consortium. The categories included: Apoptosis, Cell-cell signaling, Cell cycle, Cell motility, Cell organization and biogenesis, Developmental process, Immune and inflammation response, Metabolism, Signal transduction, Transcription and translation, Transport and Unknown. Functional definition of the genes was based on the information obtained through the Gene Link at the NCBI website (http://www.ncbi.nlm.nih.gov),
Table 1 Primers used for the real-time quantitative PCRs

\begin{tabular}{|c|c|}
\hline & Primers sequences $\left(5^{\prime}-3^{\prime}\right)$ \\
\hline \multirow[t]{2}{*}{$\beta$-Actin } & TCATCACTATCGGCAATGAG \\
\hline & CTTTACGGATGTCAACGTCA \\
\hline \multirow[t]{2}{*}{ STAT-1 } & TGAAGCTGAGACTGTTGGTG \\
\hline & GAACTCAGCTGCCAAACTTC \\
\hline \multirow[t]{2}{*}{ BTG3 } & TAGCAGGGCTCTTGATAAGG \\
\hline & CATTGGAAGAGGTGGGAATA \\
\hline \multirow[t]{2}{*}{ TMOD1 } & TGGATGAGCTAGACCCTGAT \\
\hline & СTCGTTTCTCCCCTGTGTAG \\
\hline \multirow[t]{2}{*}{ IL-6 } & CAGGGAGATCTTGGAAATGA \\
\hline & AACTCCAGAAGACCAGAGCA \\
\hline \multirow[t]{2}{*}{ PSMB9 } & GGACGCAGCTTATAAACCAG \\
\hline & TGGTGACCAGGTAGATGACA \\
\hline \multirow[t]{2}{*}{ RTN4 } & CCAGGCTATCCAGAAATCAG \\
\hline & CCGCCTCAGTTCTTTTATTG \\
\hline \multirow[t]{2}{*}{ CEACAM 1} & TGAGAAGCTCCAGACATCCT \\
\hline & CTTTGACTGTGGTGTTGGTG \\
\hline \multirow[t]{2}{*}{ IRF1 } & GACGGACTGAGCAGCTCTAC \\
\hline & CTGCATATGCCACTCAGAGA \\
\hline \multirow[t]{2}{*}{ PRKR } & GGTACTGGTTTCGGTGCTAA \\
\hline & ATAGACGAGCTGCTGGAAAA \\
\hline \multirow[t]{2}{*}{ PSME2 } & AAGGTGCTGGAGAGAGTGAA \\
\hline & TCCATTACATGGGTGTCCTT \\
\hline \multirow[t]{2}{*}{ C2TA } & GAGAACAAGATCGGGGACAA \\
\hline & GCTCAGCCTTAGGAGGGACT \\
\hline \multirow[t]{2}{*}{ TAA1 } & ТСССААСТССАСТСАТТТСС \\
\hline & TCCGATGATCAGGACACAAA \\
\hline \multirow[t]{2}{*}{ OGFR } & GCCGCGCTTCCACAATC \\
\hline & GGGCCCCCAGACAAACTC \\
\hline \multirow[t]{2}{*}{ PNLIPRP1 } & CCGGGACTTTGTGGCTTGTAACC \\
\hline & ATCGGCATAGTGACCCATCTG \\
\hline \multirow[t]{2}{*}{ CHRNB1 } & CATCGAGTCTCTCCGTGTCA \\
\hline & TGCAATTCTGCCAGTCAAAG \\
\hline \multirow[t]{2}{*}{ S100A10 } & TTGACAAAGGAGGACCTGAGA \\
\hline & CCCCGCCACTAGTGATAGAA \\
\hline \multirow[t]{2}{*}{ PER3 } & TGGCAGTGTTTTCGTTTCTG \\
\hline & CTGCAGAAAAAGGGCTTCAC \\
\hline \multirow[t]{2}{*}{ Scya2 } & ATGCAGTTAATGCCCCACTC \\
\hline & TTCCTTATTGGGGTCAGCAC \\
\hline \multirow[t]{2}{*}{ GBP2 } & CTCGACTGTGCATCAGGAAA \\
\hline & TAGGTCTGCACCAGGCTCTT \\
\hline \multirow[t]{2}{*}{ TAP1 } & TTCATGATTTGGGGGTCATT \\
\hline & GCCTAAACTTCTGGGCCTCT \\
\hline
\end{tabular}

The sense primer is listed first and the antisense primer second.

containing GeneOntology and RefSeq annotations, the Rat Genome Database link (http://rgd.mcw.edu) and specific literature references. In the case of insufficient information for the rat gene, the human homologue was searched through the Gene Link at the NCBI website (http://www.ncbi.nlm.nih.gov) and specific information obtained through the analysis of GeneOntology and RefSeq annotations, OMIM (Online Mendelian Inheritance in Man) links and specific literature references. 
Table 2 Results of the real-time quantitative PCR (QPCR) confirmation of 20 genes of the microarray and comparison of the QPCR results with the array results

\begin{tabular}{|c|c|c|c|c|c|}
\hline \multirow[b]{2}{*}{ Clone ID } & \multirow[b]{2}{*}{ Description } & \multicolumn{2}{|c|}{ QPCR results } & \multicolumn{2}{|c|}{ Array results } \\
\hline & & Fold & $P$-value & Fold & $P$-value \\
\hline AF251305 & MHC class II transactivator (C2ta) & 19.21 & $8.44 \mathrm{E}-05$ & 2.17 & $1.65 \mathrm{E}-03$ \\
\hline L12025 & Tumor-associated antigen 1 (Taa1) & 16.06 & $3.07 \mathrm{E}-12$ & 2.04 & $7.80 \mathrm{E}-05$ \\
\hline AF156878 & Opioid growth factor receptor (Ogfr) & 2.54 & $2.62 \mathrm{E}-07$ & 2.01 & $1.94 \mathrm{E}-03$ \\
\hline X61925 & Pancreatic lipase related protein 1 (Pnliprp1) & $>7.0$ & * & 2.02 & $9.13 E-05$ \\
\hline X74833 & Cholinergic receptor, nicotinic, beta polypeptide 1 (Chrnb1) & 1.56 & $5.84 \mathrm{E}-05$ & -2.05 & $1.36 \mathrm{E}-03$ \\
\hline AF465254 & Calpactin I light chain (P10 protein) (S100a10) & 3.03 & $3.95 \mathrm{E}-05$ & 1.93 & $1.96 \mathrm{E}-03$ \\
\hline AF311875 & Period homologue 3 (Drosophila) (Per3) & -2.89 & $5.28 \mathrm{E}-07$ & -2.32 & $4.54 \mathrm{E}-03$ \\
\hline AF205604 & Signal transducer and activator of transcription 1 (Stat1) & 6.06 & $7.89 \mathrm{E}-04$ & 1.98 & $6.73 E-05$ \\
\hline AF087037 & B-cell translocation gene 3 (Btg3) & 2.13 & $6.76 \mathrm{E}-05$ & 2.04 & $3.72 \mathrm{E}-07$ \\
\hline U59241 & Tropomodulin 1 (Tmod1) & -2.35 & $8.68 \mathrm{E}-11$ & 1.94 & $4.63 E-06$ \\
\hline M26744 & IL-6 (I16) & 39.2 & $3.34 \mathrm{E}-03$ & 9.88 & $9.00 \mathrm{E}-05$ \\
\hline D10757 & Proteasome subunit, beta type, 9 (Psmb9 alias Lmp2) & 2.98 & $4.38 \mathrm{E}-02$ & 2.05 & $6.35 E-05$ \\
\hline AF132046 & Nogo-A (Rtn4) & 1.50 & $2.19 \mathrm{E}-03$ & 2.05 & $5.04 \mathrm{E}-05$ \\
\hline AJ277105 & $\begin{array}{l}\text { Carcinoembryonic antigen-related cell adhesion } \\
\text { molecule } 1 \text { (Ceacam1) }\end{array}$ & -2.09 & $2.48 \mathrm{E}-06$ & -2.0 & $5.15 E-05$ \\
\hline M34253 & Interferon regulatory factor 1 (Irf1) & 5.37 & $3.39 \mathrm{E}-04$ & 2.10 & $1.35 \mathrm{E}-05$ \\
\hline L29281 & $\begin{array}{l}\text { Protein kinase, interferon-inducible double-stranded } \\
\text { RNA-dependent (Prkr) }\end{array}$ & 3.41 & $7.91 \mathrm{E}-04$ & 1.94 & $1.68 \mathrm{E}-05$ \\
\hline D45250 & Protease 28 subunit, beta (Psme2) & 2.42 & $4.70 \mathrm{E}-05$ & 1.98 & $6.73 E-05$ \\
\hline AF058786 & Small inducible cytokine A2 (Scya2) & 3030 & $5.89 \mathrm{E}-03$ & 10.10 & $7.04 \mathrm{E}-04$ \\
\hline M80367 & Guanylate binding protein 2, interferon-inducible (Gbp2) & 22.8 & $5.81 \mathrm{E}-03$ & 5.97 & $3.84 \mathrm{E}-07$ \\
\hline X57523 & Transporter 1, ABC (ATP binding cassette) (Tap1) & 20.2 & $5.66 \mathrm{E}-06$ & 4.12 & $1.41 \mathrm{E}-05$ \\
\hline
\end{tabular}

* In the control sample pancreatic lipase related protein 1 was not detectable at 40 cycles. Therefore 40 cycles was chosen as the CT value.

\section{'Humanization' of the gene list and comparison with data obtained in human PTCs}

In order to compare our gene list with the microarray data obtained by Huang et al. (2001) in human PTCs (http://thinker.med.ohio-state.edu), we applied the following strategy. First, we identified genes common to our gene list and to the HG-U95A Affymetrix oligonucleotide array used in the human tissue analysis. This task was accomplished by matching all the obtainable GenBank accession numbers of the human homologues and/or the gene symbols (obtained through Gene Link, the Homologene database (Wheeler et al. 2004) and the Nucleotide database at the NCBI website (http://www.ncbi.nlm.nih.gov)) with the gene list of the HG-U95A Affymetrix oligonucleotide array. In this way a list of genes in common between our genome and the genes analyzed in PTCs was obtained.

\section{Results and discussion}

\section{Microarray analysis and QPCR validation}

Analysis of the microarray results showed a statistically significant RET/PTC3-induced modification of expression of 270 genes after $48 \mathrm{~h}$ of activation of the oncoprotein. Of these, 172 genes were up-regulated with a fold-increase ranging from 1.18 to 17.95 and 98 down-regulated with a fold decrease ranging from -1.16 to -2.32 . There were 82 genes showing statistically significant regulation at $24 \mathrm{~h}$ (68 up-regulated and 14 down-regulated). With the exception of Hyoul ( $24 \mathrm{~h}$ $-2.48,48 \mathrm{~h} 1.32$ ), all showed consistent regulation at the two time points, in most cases with a peak of expression modification at $48 \mathrm{~h}$. To further validate the microarray results, QPCR confirmation was performed for 20 genes, 12 of which were characterized by a 1.9to 2.1-fold increase, four by a -2 - to -2.32 -fold decrease, and four others by a $>4$-fold change at $48 \mathrm{~h}$ (Table 2). Eighteen genes out of $20(90 \%)$ showed a consistent change between the microarray and the QPCR. In 15 of these, the change detected by QPCR was significantly greater. This indicates that the rigorous statistical criteria applied to the microarray data succeeded in minimizing false positive results. This is consistent with previous studies describing the validation of this technique (Guo et al. 2004, Sartor et al. 2004). However, based on previous experiments conducted in this cell line by our group, we are aware of several genes present on the microarray chip and 
known to be markedly up-regulated by RET/PTC that did not score (e.g. COX-2, vascular endothelial growth factor (VEGF), $\mathrm{PGE}_{2}$ receptor 2 (EP2), EP4) (Puxeddu et al. 2003). Therefore, it is apparent that by minimizing Type I error some true positives were missed. The strict dependence of gene expression modifications on RET/PTC3 activation, and not on antibiotic treatment, is supported by our previous studies in which we found no effects of dox on phenotype and expression of thyroid-specific genes in the rtTA control cell lines (Puxeddu et al. 2003, Wang et al. 2003). However, we did not formally perform this control in this microarray model. As the $48 \mathrm{~h}$ gene list included a larger number of genes, it was chosen for further investigation.

\section{Functional clustering}

For the purpose of functional clustering, we further restricted the gene list by using a cut-off value of 1.75-fold (Table 3). This yielded 77 genes showing upregulation and 9 down-regulation. The genes were clustered in 12 categories, namely Apoptosis, Cell-cell signaling, Cell cycle, Cell motility, Cell organization and biogenesis, Developmental processes, Immune and inflammation response, Metabolism, Signal transduction, Transcription and translation, Transport and Unknown.

\section{Genes involved in the regulation of cell growth and apoptosis}

Acute RET/PTC activation stimulates both DNA synthesis and apoptosis in thyroid cells (Wang et al. 2003). Paradoxically, very few genes belonged specifically to the Apoptosis (two) and Cell cycle (four) categories. However, at least three of these are key regulators of these biological processes. Ripk 3 has been implicated in the activation of caspases $2,-3,-7$ and -10 , in HeLa cells, implying that it might enhance the dominant FADD/caspase-8 pathway triggered by tumor necrosis factor- $\alpha$ or those of other death receptors, such as DR5 and DR6 (Kasof et al. 2000). Similarly, Tdga, cloned by differential display in conditionally immortalized rat hippocampal and septal cells undergoing cell death following differentiation with several factors, has been shown to trigger apoptosis when expressed in the hippocampal H19-7 cell line (Gomes et al. 1999). Moreover, a reduction of expression of its human homologue, PHLDA1, was observed in primary and metastatic melanomas compared with normal melanocytic nevi and its ectopic expression was associated with increased basal apoptosis in several human melanoma cell lines (Neef et al. 2002).
Recently, a functional role of interleukin (IL)-24 in autocrine regulation of growth and survival of RET/PTC3-expressing thyroid cells has been identified (Shinohara \& Rothstein 2004). However, loss of IL-24 expression in advanced cancers seems to indicate that its induction by oncogenes may support tumor growth only at the early stages of cancer development (Shinohara \& Rothstein 2004). Moreover, ectopic expression of its human homologue MDA7 in H0-1 human melanoma cells suppressed growth (Jiang et al. 1995). Similarly, infection of human breast cancer cells with a recombinant adenovirus expressing MDA7 inhibited growth and induced apoptosis, independently of the p53 status, with an increase in Bax protein and in the ratio of Bax to $\mathrm{Bcl}-2$ ( $\mathrm{Su}$ et al. 1998). Thus, the precise role of IL-24 in mediating RET/PTC3-induced oncogenic properties is still unresolved. $\mathrm{Nr} 4 \mathrm{a} 1$, although included in the Transcription and translation category because it codes for a nuclear orphan receptor, deserves to be mentioned because of its role in regulation of cell death. Indeed, its human homologue, also known as Nur77, has been shown to bind $\mathrm{Bcl}-2$ at the mitocondrial level and to trigger a conformational change of Bcl-2 that exposes its $\mathrm{BH} 3$ domain, resulting in conversion of $\mathrm{Bcl}-2$ from a cell protector to a cell killer (Lin et al. 2004). The remaining three genes in the Cell cycle category, namely Emp1, Btg3 and S100a10, code for negative regulators of cell proliferation, and their possible role in mediating RET/PTC biological effects is unclear. Up-regulation of several genes in the Cell-cell signaling, Signal transduction, Transcription and translation and eventually also in the Immune and inflammatory response categories may participate in the regulation of cell growth. Besides being implicated in cell-cell adhesion and cell migration, fibronectin (Fn1, Cell-cell signaling), has been shown to activate survival and mitogenic signals, including the MEK-ERK pathway that is particularly critical for thyroid cell transformation (Gu et al. 2002). Similarly, up-regulation of Stat3 expression (Signal transduction) and activation of Stat3 pathways exert tumorigenic functions through the induction of cell cycle genes such as cyclin D1 and cMyc and antiapoptotic genes such as Bcl-xl (Bromberg 2002). Indeed, Stat 3 has been found to be overexpressed in human PTC (Trovato et al. 2003). Moreover, RET/PTC1 has been shown to activate Stat3 phosphorylation in thyroid cells (Schuringa et al. 2001, Pedranzini et al. 2004). Ran (Signal transduction) is a small G-protein that functions in several critical processes in eukaryotic cells including nuclear transport, nuclear envelope formation and spindle formation, the last two processes being a critical component 
Table 3 Functional clustering of the genes regulated by RET/PTC3 in PCCL3 cells

Fold change

\begin{tabular}{|c|c|c|}
\hline \multicolumn{3}{|l|}{ Apoptosis } \\
\hline AF036537 & Receptor-interacting serine-threonine kinase 3 (Ripk3) & 3.16 \\
\hline AF192802 & T-cell death associated gene (Tdag) & 2.52 \\
\hline \multicolumn{3}{|c|}{ Cell-cell signaling } \\
\hline D25290 & Cadherin 6 (Cdh6) & 3.03 \\
\hline U61261 & Laminin 5 alpha 3 (Lama3) & 2.75 \\
\hline X01032 & Cholecystokinin (Cck) & 2.64 \\
\hline X15906 & Fibronectin 1 (Fn1) & 2.56 \\
\hline M25297 & Natriuretic peptide precursor type B (Nppb) & 2.49 \\
\hline AF189709 & Collagen type XVIII, alpha 1 chain (Col18a1) & 2.31 \\
\hline \multicolumn{3}{|l|}{ Cell cycle } \\
\hline Z54212 & Epithelial membrane protein 1 (Emp1) & 7.06 \\
\hline AF269251 & IL-24 (I124) & 5.88 \\
\hline AF087037 & B-cell translocation gene $3(\mathrm{Btg} 3)$ & 2.04 \\
\hline AF465254 & Calpactin I light chain (P10 protein) (S100a10) & 1.93 \\
\hline \multicolumn{3}{|l|}{ Cell motility } \\
\hline AF132046 & Nogo-A (Rtn4) & 1.85 \\
\hline AF083269 & Actin-related protein complex $1 b(\operatorname{Arpc} 1 b)$ & 1.78 \\
\hline \multicolumn{3}{|c|}{ Cell organization and biogenesis } \\
\hline U59241 & Tropomodulin 1 (Tmod1) & 1.94 \\
\hline AF306457 & RAN, member RAS oncogene family (Ran) & 1.76 \\
\hline AF028784 & Glial fibrillary acidic protein (Gfap) & 2.94 \\
\hline \multicolumn{3}{|c|}{ Developmental processes } \\
\hline Y07704 & Best5 (Best5) & 17.95 \\
\hline AF304446 & Adamts1 (Adamst1) & 9.71 \\
\hline AK034239 & Semaphorin 3C (Sema3c) & 1.88 \\
\hline AF016296 & Neuropilin (VEGF 165 receptor) (Nrp) & 1.79 \\
\hline \multicolumn{3}{|c|}{ Immune and inflammation response } \\
\hline U22520 & Interferon-induced protein $10(\mathrm{Cxcl} 10)$ & 11.90 \\
\hline AF058786 & Small inducible cytokine A2 (Scya2) & 10.10 \\
\hline M26744 & IL-6 (I16) & 7.64 \\
\hline M80367 & Guanylate binding protein 2, interferon-inducible (Gbp2) & 5.97 \\
\hline Z18877 & 25 oligoadenylate synthetase (Oas 1 ) & 4.20 \\
\hline$X 57523$ & Transporter 1, ABC (ATP binding cassette) (Tap1) & 4.12 \\
\hline L40365 & mRNA for MHC class I antigen, EU allele (RT1Aw2) & 2.77 \\
\hline AF251305 & MHC class II transactivator (C2ta) & 2.17 \\
\hline M34253 & Interferon regulatory factor 1 (Irf1) & 2.10 \\
\hline D10757 & Proteasome subunit, beta type, 9 (Psmb9 alias Lmp2) & 2.05 \\
\hline D45250 & Protease 28 subunit, beta (Psme2) & 1.98 \\
\hline L29281 & Protein kinase, interferon-inducible double stranded RNA dependent (Prkr) & 1.94 \\
\hline AJ277105 & Carcinoembryonic antigen-related cell adhesion molecule 1 (Ceacam1) & -2.02 \\
\hline X78985 & CD5 antigen $(\mathrm{Cd} 5)$ & -1.82 \\
\hline \multicolumn{3}{|l|}{ Metabolism } \\
\hline M10149 & Aldolase B (Aldob) & 10.73 \\
\hline AF162130 & MAGUK p55 subfamily member 6 (Mpp6) & 10.67 \\
\hline AF280967 & Prostaglandin E synthase 1 (Ptges) & 7.29 \\
\hline AJ278701 & Branched chain aminotransferase 1, cytosolic (Bcat1) & 5.27 \\
\hline M58364 & GTP cyclohydrolase 1 (Gch1) & 4.84 \\
\hline AJ428514 & NADH dehydrogenase subunit $2(\mathrm{Nd} 2)$ & 4.65 \\
\hline U76997 & Aminopeptidase Vp165 (Vp165) & 4.04 \\
\hline L38615 & Glutathione synthetase (Gss) & 2.98 \\
\hline U18942 & Adenosine deaminase, RNA-specific (Adar) & 2.40 \\
\hline X61925 & Pancreatic lipase related protein 1 (Pnliprp1) & 2.02 \\
\hline AF010306 & Cathepsin K (Ctsk) & 1.79 \\
\hline $\mathrm{X} 67654$ & Glutathione S-transferase 1 (theta) (Gstt1) & 1.75 \\
\hline M88344 & Cystathionine beta synthase (Cbs) & -1.97 \\
\hline
\end{tabular}




\section{Fold change}

\begin{tabular}{|c|c|c|}
\hline \multicolumn{3}{|c|}{ Signal transduction } \\
\hline AJ249240 & Suppressor of cytokine signaling 3 (Socs3) & 5.14 \\
\hline Y18812 & Glutamate receptor, metabotropic 1 (Grm1) & 4.14 \\
\hline D45201 & Neurofibromatosis type 1 (Nf1) & 2.59 \\
\hline L13041 & Calcitonin receptor (Calcr) & 2.46 \\
\hline AJ000557 & Janus kinase 2 (Jak2) & 2.40 \\
\hline AF013144 & MAP-kinase phosphatase (Cpg21) & 2.32 \\
\hline U42627 & Dual specificity phosphatase 6 (Dusp6) & 2.24 \\
\hline AJ243123 & Suppressor of cytokine signaling 1 (Socs1) & 2.09 \\
\hline AF156878 & Opioid growth factor receptor (Ogfr) & 2.01 \\
\hline AF205604 & Signal transducer and activator of transcription 1 (Stat1) & 1.98 \\
\hline L06441 & Decidual prolactin-related protein (Dtprp) & 1.85 \\
\hline U40652 & Protein tyrosine phosphatase, receptor type, N (Ptprn) & 1.81 \\
\hline X91810 & Signal transducer and activator of transcription 3 (Stat3) & 1.80 \\
\hline AF065161 & Cytokine inducible $\mathrm{SH} 2$-containing protein (Cish) & 1.79 \\
\hline M22924 & Membrane-spanning 4-domains, subfamily A, member 2 (Ms4a2) & 1.75 \\
\hline L27081 & Melanocortin 5 receptor (Mc5r) & 1.75 \\
\hline X74833 & Cholinergic receptor, nicotinic, beta polypeptide 1 (Chrnb1) & -2.05 \\
\hline \multicolumn{3}{|c|}{ Transcription and translation } \\
\hline U17254 & Immediate early gene transcription factor NGFI-B (Nr4a1) & 2.92 \\
\hline M29039 & Jun B proto-oncogene (Junb) & 2.90 \\
\hline L13201 & HNF-3/forkhead homolog-1 (Hfh1) & 2.88 \\
\hline L35271 & Runt-related transcription factor 1 (Runx1) & 2.75 \\
\hline AB025017 & TIS11 (Zpf36) & 1.77 \\
\hline Y11321 & Forkhead box E1 (thyroid transcription factor 2) (Foxe1) & -1.78 \\
\hline \multicolumn{3}{|l|}{ Transport } \\
\hline X60729 & beta-hO-r gene for beta-globin chain (Betahor) & 10.07 \\
\hline AB002801 & Cyclic nucleotide gated channel alpha 3 (Cnga3) & 3.61 \\
\hline AF144082 & Aquaporin 4 (Aqp4) & 2.91 \\
\hline M85299 & Solute carrier family 9 , member 1 (S1c9a1) & 2.84 \\
\hline X98399 & Solute carrier family 14 , member 1 (S1c14a1) & 2.19 \\
\hline $\mathrm{BC} 003281$ & $\mathrm{~B}$ aggressive lymphoma (Ba1) & 1.86 \\
\hline AJ003065 & Potassium inwardly-rectifying channel J14 (Kcnj14) & 1.76 \\
\hline \multicolumn{3}{|l|}{ Unknown } \\
\hline U07619 & Coagulation factor $3(\mathrm{~F} 3)$ & 3.37 \\
\hline L12025 & Tumor-associated antigen 1 (Taa1) & 2.04 \\
\hline AF065438 & Peptidylprolyl isomerase C-associated protein (Ppicap) & 1.79 \\
\hline BC005419 & Interferon- $\gamma$ induced GTPase (Gtpi-pending) & 1.75 \\
\hline AF311875 & Period homologue 3 (Drosophila) (Per3) & -2.32 \\
\hline M18839 & T-cell receptor active beta-chain V-region (V-beta10-J-beta2.5) (M18839) & -2.01 \\
\hline AF034900 & Olfactory receptor-like protein (SCR D-7) & -2.00 \\
\hline AF054270 & Prolactin-inducible protein (Pip) & -1.85 \\
\hline
\end{tabular}

of cell cycle progression (Li \& Zheng 2004). The Runx 1/Amll gene (Transcription and translation) is one of the most frequently mutated genes associated with human acute leukemia and encodes the DNA-binding subunit of the heterodimeric transcriptional factor complex that also includes core-binding factor (Ito 2004). Its function is not completely understood, but is believed to be related to lymphohematopoiesis. Finally, Santoro et al. (Castellone 2004b) have shown that $\mathrm{Cxcl10}$ and Scya2 (Immune and inflammation) are expressed in PCCL3 cells after chronic activation of RET/PTC and that chemokines, such as Cxcl10, may have a role in the promotion of cell proliferation and invasiveness.

RET/PTC induces expression of genes involved in the glycolytic cascade (such as Aldob and Nd2), amino acid metabolism (such as Bcat1, Vp165, Ctsk, Cbs) and lipid metabolism (such as Pnliprp1). This would be expected to increase metabolic activity consistent with the requirements for cell proliferation. The 
oncoprotein also induced genes involved in the protection of cells from oxidative damage by free radicals and detoxification of xenobiotics (such as Gss and Gstt1), and in water and solute transport (such as Aqp 4, Slc9a1, Slc14a1, Bal, Kcnj14).

RET/PTC was found to induce microsomal PGE synthase 1 (Ptges), a key enzyme in $\mathrm{PGE}_{2}$ biosynthesis. Besides mPGES1, RET/PTC also induces expression of COX-2, resulting in marked stimulation of $\mathrm{PGE}_{2}$ (Puxeddu et al. 2003). $\mathrm{PGE}_{2}$ in turn may play a role in autocrine tumor growth regulation, besides having immunomodulatory properties and serving as a promoter of angiogenesis (Murakami \& Kudo 2004). Several studies have demonstrated increased COX-2 immunostaining in human thyroid adenomas and carcinomas (Cornetta et al. 2002, Specht et al. 2002). To the best of our knowledge there are no published clinical trials examining the effects of COX antagonists on thyroid tumor formation or progression. A recent report described inhibition of growth of the PTC cell line TPC-1 expressing RET/PTC1 by the specific COX-2 inhibitor NS-398 (Kajita et al. 2005).

\section{Genes involved in metastasis and angiogenesis}

Some of the genes included in the Cell-cell signaling, Cell motility, Developmental processes and in the Metabolism categories, may participate in the acquisition of invasiveness, metastatic potential and angiogenesis. Cadherin (Cdh6) and fibronectin (Fn1) (Cell-cell signaling category) have been implicated in the activation of cell motility and metastasis (Shimoyama et al. 1995, Clark et al. 2000). Moreover, Arpc1b (Cell motility category) may directly mediate modifications of the cytoskeleton required for cell motility (Welch et al. 1997). As mentioned above, RET/PTC induces expression of rate-limiting enzymes involved in PG biosynthesis, which could be significant in promotion of angiogenesis via $\mathrm{PGE}_{2}$. In addition, VEGF is also up-regulated by RET/PTC, although this gene product did not score in the microarray. By contrast, Adamts1 (Vazquez et al. 1999) (Developmental processes) and a product of Col18a 1 catabolism, endostatin (O'Reilly et al. 1997), exert antiangiogenetic functions. The balance between the production of angiogenetic and of angiostatic factors may be important for the ordered development of new vessels in the developing tumoral lesion. This phenomenon may help explain the rarity of progression of microcarcinomas to clinically significant forms of the disease, with the latter being characterized by the capacity to actively promote capillary development (Folkman \& Kalluri 2004).

\section{Genes involved in signal transduction}

The Signal transduction category included 16 upregulated genes and one down-regulated gene. Three genes up-regulated by RET/PTC3, namely Cpg21, Dusp6 and Nf1 are negative regulators of the RAS-BRAF-MAPK signal transduction pathway, known to be activated by RET/PTC3. Cpg21, which is homologous to the human dual-specificity phosphatase DUSP5, inactivates ERK-1 (Ishibashi et al. 1994), whereas DUSP6 inactivates ERK-2 (Muda et al. 1996), while Nf1, the product of the neurofibromatosis tumor suppressor gene, is a negative regulator of RAS intracellular signaling (Reed \& Gutmann 2001). The induction of expression of these three genes may reflect a compensatory mechanism aimed to terminate signaling through the MAPK pathway to maintain cellular homeostasis. The Signal transduction category includes also Socs3, Jak2, Socs1, Stat1, Ptprn, Stat3 and Cish, all of which regulate pathways activated by the cell surface cytokine receptor superfamily (Balkwill 2004, Howard \& Galligan 2004). As discussed in the following sections, these genes may drive signal transduction pathways involved in the regulation of the immune response.

\section{Genes involved in loss of differentiation}

Sustained expression of RET/PTC1 (De Vita et al. 1998) or acute expression of RET/PTC1 and RET/ PTC3 (Wang et al. 2003) in PCCL3 cells is associated with loss of thyroid-specific differentiated properties, manifesting as impaired expression of TSH receptor (TSHR), thyroid peroxidase, thyroglobulin ( $\mathrm{Tg}$ ) and the sodium iodide symporter. This is due in part to loss of expression or activity of the thyroid transcription factors Pax8 and TTF1 (De Vita et al. 1998) or with interference of TSHR-mediated intracellular signaling at sites distal to TSHR (Wang et al. 2003). This present study was not designed to look at the impact on thyroid differentiation, because cells were not maintained in the presence of TSH. Despite this, expression of Foxe1 (also known as Ttf2) (Zannini et al. 1997), a forkhead domain transcription factor thought to play a role in the early stages of thyroid cell differentiation, was decreased by RET/PTC3.

\section{Genes involved in the regulation of the immune response}

Twelve up-regulated and two down-regulated genes belonged to the Immune and inflammation response 
category. Three of these code for chemokines or cytokines (Cxcl10, Scya2, IL-6) potentially involved in the modulation of the immune response (Houshmand \& Zlotnik 2003). Three others code for signaling proteins (Gbp2, C2ta, Irf1) that together with seven others previously mentioned in the Signal transduction category (Socs3, Jak2, Socs1, Stat1, Ptprn, Stat3, Cish) are known to mediate intracellular transduction of cytokines (Samuel 2001, Houshmand \& Zlotnik 2003, van den Elsen et al. 2004). Four genes are known to be involved in the regulation of antigen presentation to cytotoxic $\mathrm{T}$ cells, whose expression is typically IFN-dependent (Tap1, RT1Aw2, Lmp2, Psme2) (Marincola et al. 2000, 2003). Two additional IFN-regulated genes, Oas1 and Prkr, code for molecules typically expressed during viral infection and involved in its elimination. Although Adar has similar activity, because of its broader spectrum of action it is listed in the Metabolism category (Samuel 2001). Finally, two adhesion molecules, Ceacam 1 and Cd5, were down-regulated. Ceacam1, also known as CD66a, has been shown to protect melanoma cells from natural killer (NK) cell cytotoxicity (Markel et al. 2002). Conceivably, CD66a down-regulation may increase thyroid cell susceptibility to NK lysis. Cd5 is instead generally expressed on the surface of lymphocytes and is considered as an inhibitor of antigen receptor-mediated signals in $\mathrm{T}$ cells. The explanation for its expression in PCCL3 cells and its down-regulation after RET/PTC3 activation is not clear.

In summary, the genes specifically involved in the regulation of the immune response represented $16.3 \%$ (14 of 86) of the entire list considered for the functional clustering. Moreover, the proportion increases if genes with broader function are included, as described above (22 of $86,25.6 \%$ ). The strong representation of immune and inflammation response-related genes after RET/PTC activation points to a critical role of this oncoprotein in the early modulation of the immune response. Immune surveillance systems may operate at early stages of tumorigenesis, possibly activated by the formation of neoantigens or by perturbation of the antigen density resulting from genetic alterations and major genetic instability (Marincola et al. 2000). Our data raise the possibility that activation of RET/ PTC induces immunogenicity of the tumor cell through up-regulation of the MHC class I antigenpresenting machinery and by down-regulation of molecules involved in protection from NK cytotoxicity.

Many of the genes of this category (Cxcl10, Gbp2, C2ta, Tap1, RT1Aw2, Lmp2, Psme2, Oas1, Prkr), and some included in other functional subgroups (Best5, Gtpi-pending, Adar), are typically induced by IFN$\alpha /-\beta$ and/or $-\gamma$. Paradoxically, IFN- $\alpha,-\beta$ and $-\gamma$ mRNA was not significantly up-regulated by RET/PTC3 in the microarray. Thus, IFN-independent upstream effectors may be involved in those events. Indeed, there is recent evidence that RET/PTC interacts with and constitutively activates Stat 1 through mechanisms that do not require Jak or Src (Hwang et al. 2004). The induction and activation of Stat 1 may account for the up-regulation of so many IFN-responsive genes, such as Irf1 and C2ta, previously described as RET/PTC targets (Hwang et al. 2004), most of which are involved in activation of the immune response. However, RET/PTC also activates Stat3 (Hwang et al. 2003), which may exert primarily inhibitory effects on the immune response. Indeed, Stat3 activation was shown to inhibit the immune response elicited by tumor cells by suppressing release of proinflammatory mediators or by repressing the functional maturation of dendritic cells (Wang et al. 2004). We show that RET/PTC3 up-regulates Stat3 expression, which may amplify the effects following RET-mediated phosphorylation of Stat3. Moreover, Stat3 may also be further activated in a paracrine fashion through IL-6, which is also up-regulated by RET/PTC.

Ligand activation of c-RET, as well as oncogenic forms of RET, can activate nuclear factor- $\kappa \mathrm{B}(\mathrm{NF}-\mathrm{\kappa B})$ (Visconti et al. 1997, Hayashi et al. 2000, Ludwig et al. 2001). NF- $\kappa B$ in turn promotes the transcription of many proinflammatory cytokines and in our model may account for the up-regulation of Scya2 (Russell et al. 2003) and IL-6 (Kikumori et al. 1998). Scya-2, also known as MCP1, IL-6 and CXCL10 (also known as IP10), may represent key regulators of chemoattraction of inflammatory cells and lymphocytes at the tumor formation site. Interestingly, NF- $\kappa B$ and proinflammatory mediators induced by NF- $\kappa \mathrm{B}$ activation, produced either by cells of the immune system or by transformed cells, were recently shown to mediate tumor promotion in two mouse models of inflammation-associated cancers (Greten et al. 2004, Pikarsky et al. 2004).

In conclusion, RET/PTC3 may potentially increase tumor cell immunogenicity through the regulation of IFN-responsive genes, such as those involved in MHC class I antigen-presentation to cytotoxic T cells (Tap1, RT1Aw2, Lmp2, Psme2), eventually increasing susceptibility to NK lysis, and through the up-regulation of cytokines/chemokines involved in the recruitment and activation of cells of the immune system. RET/ PTC3 also activates Stat3, which may promote 


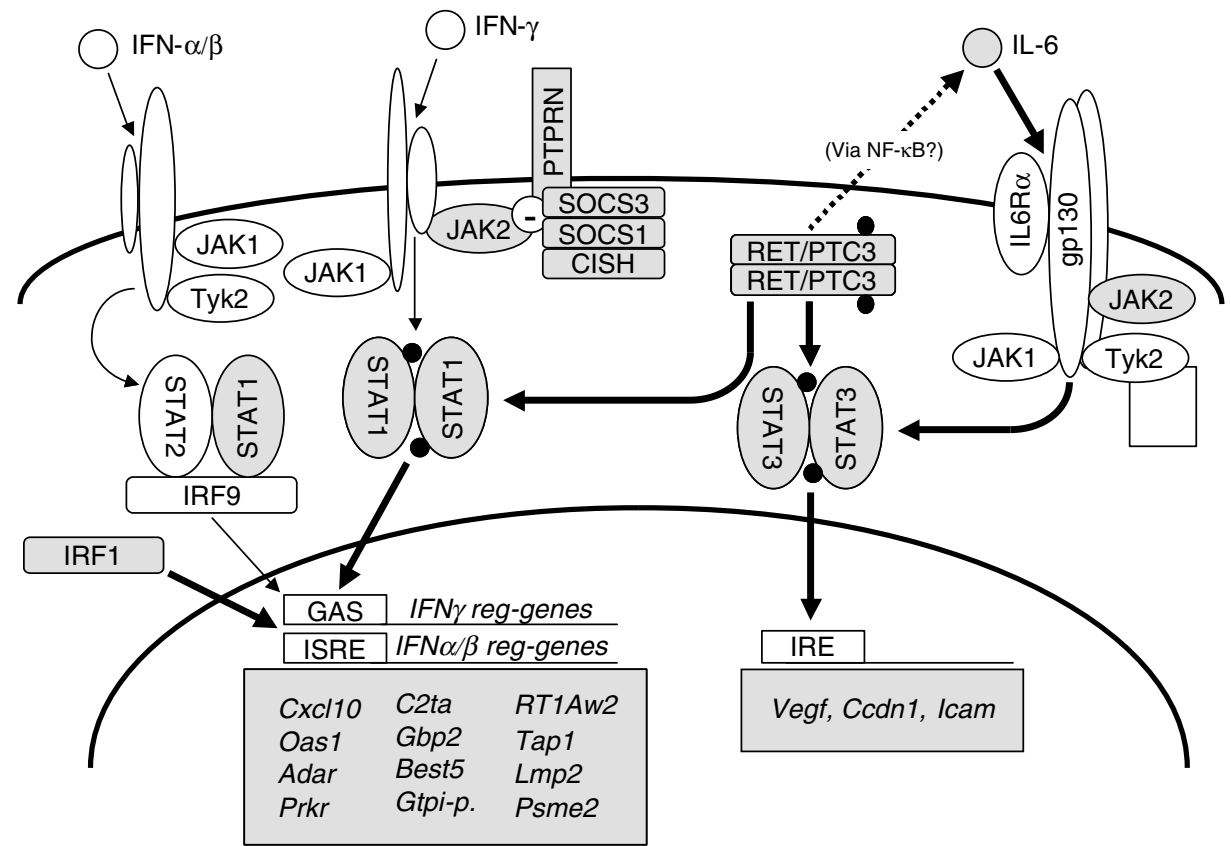

Figure 2 Schematic map of the relationships between RET/PTC3 and IFN- and cytokine-activated signal transduction pathways according to the microarray results and to the literature. Up-regulated genes are shaded, whereas black dots indicate activation by phosphorylation. RET/PTC3 induces the expression of Stat1 and Stat3, involved respectively in the regulation of IFN and cytokine (e.g. IL-6) signal transduction pathways. RET/PTC3 also activates both transcription factors through direct phosphorylation of critical tyrosine residues (Hwang et al. 2003, Hwang et al. 2004) and through increased IL-6 expression, possibly via NF-KB (Visconti et al. 1997, Ludwig et al. 2001), stimulates Stat3 activation. In addition RET/PTC3 induces the expression of additional components of these two pathways, such as Jak2, Socs1 and 3, Cish and Ptprn. RET/PTC3-induced activation of Stat1 results in the up-regulation of IFN-responsive genes, whereas RET/PTC1 or RET/PTC3-induced activation of Stat3 results in the up-regulation of Vegf, Cyclin D1 and Icam (Hwang et al. 2003).

Table 4 Results of the comparison of the expression profile of PCCL3 cells expressing RET/PTC3 with the expression profiles of papillary thyroid carcinomas reported by Huang et al. (2001)

\begin{tabular}{lllrrr}
\hline $\begin{array}{l}\text { Rat } \\
\text { clone ID }\end{array}$ & $\begin{array}{l}\text { Human } \\
\text { clone ID }\end{array}$ & Description & \multicolumn{2}{c}{ Fold change } \\
\cline { 3 - 6 } M80367 & M55543 & Guanylate binding protein 2, interferon-inducible (Gbp2) & Rat & Human & $\boldsymbol{P}$-value \\
D25290 & D31784 & Cadherin 6 (Cdh6) & 6.0 & 2.1 & 0.19 \\
L38615 & U34683 & Glutathione synthetase (Gss) & 3.0 & 1.5 & 0.35 \\
L35271 & D43969 & Runt-related transcription factor 1 (Runx1) & 3.0 & 1.9 & 0.47 \\
X15906 & X02761 & Fibronectin 1 (FN1) & 2.8 & 7.9 & 0.01 \\
AF013144 & U15932 & MAP-kinase phosphatase (Cpg21)/Dual specificity phosphatase 5 (DUSP5) & 2.6 & 10.2 & 0.00 \\
U42627 & AB013382 & Dual specificity phosphatase 6 (DUSP6) & 5.3 & 0.02 \\
AF087037 & D64110 & B-cell translocation gene 3 (BTG3) & 2.2 & 4.7 & 0.00 \\
AF205604 & M97935 & Signal transducer and activator of transcription 1 (Stat1) & 2.0 & 1.5 & 0.02 \\
AJ277105 & X16354 & Carcinoembryonic antigen-related cell adhesion molecule 1 (Ceacam1) & -2.0 & 1.9 & 0.11 \\
\hline
\end{tabular}

immune evasion by blocking production and responsiveness to inflammatory signals arising from multiple components of the immune system (Wang et al. 2004) (Fig. 2). How the combined effects of Stat1 and Stat3 may be contributing to the ultimate immune response remains speculative.

\section{Comparison of the expression profile of PCCL3 cells expressing RET/PTC3 with the expression profiles of PTCs}

The PCCL3 cell line is a well-differentiated clonal line derived from rat thyroid. Previous studies have 
demonstrated shared properties with normal thyroid follicular cells (e.g. dependence on TSH for growth, capacity to uptake iodine and secrete $\mathrm{Tg}$, necessity of multiple oncogenic events to induce transformation) (Fusco et al. 1987). Thus, it represents a convenient in vitro model to study aspects of thyroid cell pathophysiology. Comparison of the expression profile of PCCL3 cells expressing RET/PTC3 with the expression profile of PTCs reported by Huang et al. (2001) yielded a handful of genes that are commonly regulated (Table 4). However, these tumors were not genotyped for mutations of $R E T / P T C, R A S$ or $B R A F$, so it is not possible to determine from this limited set of tumors which of the genes acutely regulated by RET/ PTC in thyroid cells in vitro are similarly modulated in human cancers. Moreover, the statistical criteria used for analysis of the microarray data from the human samples were less stringent, and the actual number of genes differentially regulated in the PTC samples much lower. Nevertheless, these types of comparisons may in the future yield important insights into the pathogenesis of PTCs, by linking the genes expressed in cancer tissues to specific oncogenic events.

\section{Acknowledgements}

This work was supported in part by NIH grant CA50706 (J A F). The authors declare that there is no conflict of interest that would prejudice the impartiality of this scientific work.

\section{References}

Arighi E, Alberti L, Torriti F, Ghizzoni S, Rizzetti MG, Pelicci G, Pasini B, Bongarzone I, Piutti C, Pierotti MA et al. 1997 Identification of Shc docking site on Ret tyrosine kinase. Oncogene 14 773-782.

Balkwill F 2004 Cancer and the chemokine network. Nature Reviews. Cancer 4 540-550.

Benjamini Y, Drai D, Elmer G, Kafkafi N \& Golani I 2001 Controlling the false discovery rate in behavior genetics research. Behavioural Brain Research 125 279-284.

Bongarzone I, Fugazzola L, Vigneri P, Mariani L, Mondellini P, Pacini F, Basolo F, Pinchera A, Pilotti S \& Pierotti MA 1996 Age-related activation of the tyrosine kinase receptor protooncogenes RET and NTRK1 in papillary thyroid carcinoma. Journal of Clinical Endocrinology and Metabolism 81 2006-2009.

Borrello MG, Alberti L, Arighi E, Bongarzone I, Battistini C, Bardelli A, Pasini B, Piutti C, Rizzetti MG, Mondellini P et al. 1996 The full oncogenic activity of Ret/ptc2 depends on tyrosine 539, a docking site for phospholipase Cgamma. Molecular and Cellular Biology 16 2151-2163.
Bromberg J 2002 Stat proteins and oncogenesis. Journal of Clinical Investigation 109 1139-1142.

Castellone MD, Celetti A, Guarino V, Cirafici AM, Basolo F, Giannini R, Medico E, Kruhoffer M, Orntoft TF, Curcio F et al. 2004 a Autocrine stimulation by osteopontin plays a pivotal role in the expression of the mitogenic and invasive phenotype of RET/PTCtransformed thyroid cells. Oncogene 23 2188-2196.

Castellone MD, Guarino V, De Falco, V, Carlomagno F, Basolo F, Faviana P, Kruhoffer M, Orntoft T, Russell JP, Rothstein JL et al. 2004 b Functional expression of the CXCR4 chemokine receptor is induced by RET/PTC oncogenes and is a common event in human papillary thyroid carcinomas. Oncogene 23 5958-5967.

Chan KS, Sano S, Kiguchi K, Anders J, Komazawa N, Takeda J \& DiGiovanni J 2004 Disruption of Stat3 reveals a critical role in both the initiation and the promotion stages of epithelial carcinogenesis. Journal of Clinical Investigation 114 720-728.

Clark EA, Golub TR, Lander ES \& Hynes RO 2000 Genomic analysis of metastasis reveals an essential role for RhoC. Nature 406 532-535.

Cornetta AJ, Russell JP, Cunnane M, Keane WM \& Rothstein JL 2002 Cyclooxygenase-2 expression in human thyroid carcinoma and Hashimoto's thyroiditis. Laryngoscope 112 238-242.

DeRisi J, Penland L, Brown PO, Bittner ML, Meltzer PS, Ray M, Chen Y, Su YA \& Trent JM 1996 Use of a cDNA microarray to analyse gene expression patterns in human cancer. Nature Genetics 14 457-460.

De Vita G, Zannini M, Cirafici AM, Melillo RM, Di Lauro R, Fusco A \& Santoro M 1998 Expression of the RET/ PTC1 oncogene impairs the activity of TTF-1 and Pax-8 thyroid transcription factors. Cell Growth and Differentiation 9 97-103.

Durick K, Yao VJ, Borrello MG, Bongarzone I, Pierotti MA \& Taylor SS 1995 Tyrosines outside the kinase core and dimerization are required for the mitogenic activity of RET/ptc2. Journal of Biological Chemistry 270 24642-24645.

Durick K, Gill GN \& Taylor SS 1998 Shc and Enigma are both required for mitogenic signaling by Ret/ptc2. Molecular and Cellular Biology 18 2298-2308.

Folkman J \& Kalluri R 2004 Cancer without disease. Nature 427787.

Fugazzola L, Pilotti S, Pinchera A, Vorontsova TV, Mondellini P, Bongarzone I, Greco A, Astakhova L, Butti MG \& Demidchik EP 1995 Oncogenic rearrangements of the RET proto-oncogene in papillary thyroid carcinomas from children exposed to the Chernobyl nuclear accident. Cancer Research 55 5617-5620.

Fusco A, Berlingieri MT, Di Fiore PP, Portella G, Grieco M \& Vecchio G 1987 One- and two-step transformations of rat thyroid epithelial cells by retroviral oncogenes. Molecular and Cellular Biology 7 3365-3370.

Gomes I, Xiong W, Miki T \& Rosner MR 1999 A proline- and glutamine-rich protein promotes 
apoptosis in neuronal cells. Journal of Neurochemistry 73 612-622.

Greten FR, Eckmann L, Greten TF, Park JM, Li ZW, Egan LJ, Kagnoff MF \& Karin M 2004 IKKbeta links inflammation and tumorigenesis in a mouse model of colitis-associated cancer. Cell 118 285-296.

Gu J, Fujibayashi A, Yamada KM \& Sekiguchi K 2002 Laminin-10/11 and fibronectin differentially prevent apoptosis induced by serum removal via phosphatidylinositol 3-kinase/Akt- and MEK1/ERKdependent pathways. Journal of Biological Chemistry 277 19922-19928.

Guo J, Sartor M, Karyala S, Medvedovic M, Kann S, Puga A, Ryan P \& Tomlinson CR 2004 Expression of genes in the TGF-beta signaling pathway is significantly deregulated in smooth muscle cells from aorta of aryl hydrocarbon receptor knockout mice. Toxicology and Applied Pharmacology 194 79-89.

Hayashi H, Ichihara M, Iwashita T, Murakami H, Shimono Y, Kawai K, Kurokawa K, Murakumo Y, Imai T, Funahashi $\mathrm{H}$ et al. 2000 Characterization of intracellular signals via tyrosine 1062 in RET activated by glial cell line-derived neurotrophic factor. Oncogene 19 4469-4475.

Hochberg Y \& Benjamini Y 1990 More powerful procedures for multiple significance testing. Statistics in Medicine 9 811-881.

Houshmand P \& Zlotnik A 2003 Therapeutic applications in the chemokine superfamily. Current Opinion in Chemical Biology 7 457-460.

Howard OM \& Galligan CL 2004 An expanding appreciation of the role chemokine receptors play in cancer progression. Current Pharmaceutical Design 10 2377-2389.

Huang Y, Prasad M, Lemon WJ, Hampel H, Wright FA, Kornacker K, LiVolsi V, Frankel W, Kloos RT, Eng C et al. 2001 Gene expression in papillary thyroid carcinoma reveals highly consistent profiles. PNAS 98 15044-15049.

Hwang ES, Kim DW, Hwang JH, Jung HS, Suh JM, Park YJ, Chung HK, Song JH, Park KC, Park SH et al. 2004 Regulation of STAT1 and STAT1-dependent genes by RET/PTC (rearranged in transformation/papillary thyroid carcinoma) oncogenic tyrosine kinases. Molecular Endocrinology 18 2672-2684.

Hwang JH, Kim DW, Suh JM, Kim H, Song JH, Hwang ES, Park KC, Chung HK, Kim JM, Lee TH et al. 2003 Activation of signal transducer and activator of transcription 3 by oncogenic RET/PTC (rearranged in transformation/papillary thyroid carcinoma) tyrosine kinase roles in specific gene regulation and cellular transformation. Molecular Endocrinology 17 1155-1166.

Ishibashi T, Bottaro DP, Michieli P, Kelley CA \& Aaronson SA 1994 A novel dual specificity phosphatase induced by serum stimulation and heat shock. Journal of Biological Chemistry 269 29897-29902.

Ito T, Seyama T, Iwamoto KS, Hayashi T, Mizuno T, Tsuyama N, Dohi K, Nakamura N \& Akiyama M 1993
In vitro irradiation is able to cause RET oncogene rearrangement. Cancer Research 53 2940-2943.

Ito Y 2004 Oncogenic potential of the RUNX gene family 'overview'. Oncogene 23 4198-4208.

Jhiang SM, Sagartz JE, Tong Q, Parker-Thornburg J, Capen CC, Cho JY, Xing S \& Ledent C 1996 Targeted expression of the ret/PTC1 oncogene induces papillary thyroid carcinomas. Endocrinology 137 375-378.

Jiang H, Lin JJ, Su ZZ, Goldstein NI \& Fisher PB 1995 Subtraction hybridization identifies a novel melanoma differentiation associated gene, mda-7, modulated during human melanoma differentiation, growth and progression. Oncogene 11 2477-2486.

Kajita S, Ruebel KH, Casey MB, Nakamura N \& Lloyd RV 2004 Role of COX-2, thromboxane A(2) synthase, and prostaglandin $\mathrm{I}(2)$ synthase in papillary thyroid carcinoma growth. Modern Pathology 18 221-227.

Kasof GM, Prosser JC, Liu D, Lorenzi MV \& Gomes BC 2000 The RIP-like kinase, RIP3, induces apoptosis and NF-kappaB nuclear translocation and localizes to mitochondria. FEBS Letters 473 285-291.

Kebebew E, Treseler PA, Ituarte PH \& Clark OH 2001 Coexisting chronic lymphocytic thyroiditis and papillary thyroid cancer revisited. World Journal of Surgery $\mathbf{2 5}$ 632-637.

Kikumori T, Kambe F, Nagaya T, Imai T, Funahashi H \& Seo H 1998 Activation of transcriptionally active nuclear factor-kappaB by tumor necrosis factor-alpha and its inhibition by antioxidants in rat thyroid FRTL-5 cells. Endocrinology 139 1715-1722.

Li HY \& Zheng Y 2004 Phosphorylation of RCC1 in mitosis is essential for producing a high RanGTP concentration on chromosomes and for spindle assembly in mammalian cells. Genes and Development 18 512-527.

Lin B, Kolluri SK, Lin F, Liu W, Han YH, Cao X, Dawson MI, Reed JC \& Zhang XK 2004 Conversion of Bcl-2 from protector to killer by interaction with nuclear orphan receptor Nur77/TR3. Cell 116 527-540.

Ludwig L, Kessler H, Wagner M, Hoang-Vu C, Dralle H, Adler G, Bohm BO \& Schmid RM 2001 Nuclear factorkappaB is constitutively active in C-cell carcinoma and required for RET-induced transformation. Cancer Research 61 4526-4535.

Marincola FM, Jaffee EM, Hicklin DJ \& Ferrone S 2000 Escape of human solid tumors from T-cell recognition molecular mechanisms and functional significance. Advances in Immunology 74 181-273.

Marincola FM, Wang E, Herlyn M, Seliger B \& Ferrone S 2003 Tumors as elusive targets of T-cell-based active immunotherapy. Trends in Immunology 24 335-342.

Markel G, Lieberman N, Katz G, Arnon TI, Lotem M, Drize O, Blumberg RS, Bar-Haim E, Mader R, Eisenbach L et al. 2002 CD66a interactions between human melanoma and NK cells a novel class I MHC-independent inhibitory mechanism of cytotoxicity. Journal of Immunology 168 2803-2810. 
Mizuno T, Kyoizumi S, Suzuki T, Iwamoto KS \& Seyama T 1997 Continued expression of a tissue specific activated oncogene in the early steps of radiation-induced human thyroid carcinogenesis. Oncogene 15 1455-1460.

Muda M, Boschert U, Dickinson R, Martinou JC, Martinou I, Camps M, Schlegel W \& Arkinstall S 1996 MKP-3, a novel cytosolic protein-tyrosine phosphatase that exemplifies a new class of mitogen-activated protein kinase phosphatase. Journal of Biological Chemistry 271 4319-4326.

Muller PY, Janovjak H, Miserez AR \& Dobbie Z 2002 Processing of gene expression data generated by quantitative real-time RT-PCR. Biotechniques 32 1372-1379.

Murakami M \& Kudo I 2004 Recent advances in molecular biology and physiology of the prostaglandin E2biosynthetic pathway. Progress in Lipid Research 43 3-35.

Neef R, Kuske MA, Prols E \& Johnson JP 2002 Identification of the human PHLDA1/TDAG51 gene down-regulation in metastatic melanoma contributes to apoptosis resistance and growth deregulation. Cancer Research 62 5920-5929.

Nikiforov YE 2002 RET/PTC rearrangement in thyroid tumors. Endocrine Pathology 13 3-16.

Nikiforov YE, Rowland JM, Bove KE, Monforte-Munoz H \& Fagin JA 1997 Distinct pattern of ret oncogene rearrangements in morphological variants of radiationinduced and sporadic thyroid papillary carcinomas in children. Cancer Research 57 1690-1694.

Nikiforov YE, Koshoffer A, Nikiforova M, Stringer J \& Fagin JA 1999 Chromosomal breakpoint positions suggest a direct role for radiation in inducing illegitimate recombination between the ELE1 and RET genes in radiation-induced thyroid carcinomas. Oncogene $\mathbf{1 8}$ 6330-6334.

Nikiforova MN, Stringer JR, Blough R, Medvedovic M, Fagin JA \& Nikiforov YE 2000 Proximity of chromosomal loci that participate in radiationinduced rearrangements in human cells. Science $\mathbf{2 9 0}$ 138-141.

O'Reilly MS, Boehm T, Shing Y, Fukai N, Vasios G, Lane WS, Flynn E, Birkhead JR, Olsen BR \& Folkman J 1997 Endostatin an endogenous inhibitor of angiogenesis and tumor growth. Cell $\mathbf{8 8}$ 277-285.

Pedranzini L, Leitch A \& Bromberg J 2004 Stat3 is required for the development of skin cancer. Journal of Clinical Investigation 114 619-622.

Pikarsky E, Porat RM, Stein I, Abramovitch R, Amit S, Kasem S, Gutkovich-Pyest E, Urieli-Shoval S, Galun E \& Ben Neriah Y 2004 NF-kappaB functions as a tumour promoter in inflammation-associated cancer. Nature 431 461-466.

Powell DJ, Russell J, Nibu K, Li G, Rhee E, Liao M, Goldstein M, Keane WM, Santoro M, Fusco A et al. 1998 The RET/PTC3 oncogene metastatic solid-type papillary carcinomas in murine thyroids. Cancer Research $\mathbf{5 8}$ $5523-5528$.
Powell DJ Jr, Russell JP, Li G, Kuo BA, Fidanza V, Huebner K \& Rothstein JL 2001 Altered gene expression in immunogenic poorly differentiated thyroid carcinomas from RET/PTC3p53 - / - mice. Oncogene 20 3235-3246.

Powell DJ Jr, Eisenlohr LC \& Rothstein JL 2003 A thyroid tumor-specific antigen formed by the fusion of two self proteins. Journal of Immunology 170 861-869.

Puxeddu E, Mitsutake N, Knauf JA, Moretti S, Kim HW, Seta KA, Brockman D, Myatt L, Millhorn DE \& Fagin JA 2003 Microsomal prostaglandin E2 synthase-1 is induced by conditional expression of RET/PTC in thyroid PCCL3 cells through the activation of the MEK-ERK pathway. Journal of Biological Chemistry 278 52131-52138.

Reed N \& Gutmann DH 2001 Tumorigenesis in neurofibromatosis: new insights and potential therapies. Trends in Molecular Medicine 7 157-162.

Russell JP, Shinohara S, Melillo RM, Castellone MD, Santoro M \& Rothstein JL 2003 Tyrosine kinase oncoprotein, RET/PTC3, induces the secretion of myeloid growth and chemotactic factors. Oncogene 22 4569-4577.

Samuel CE 2001 Antiviral actions of interferons. Clinical Microbiology Reviews 14 778-809.

Santoro M, Chiappetta G, Cerrato A, Salvatore D, Zhang L, Manzo G, Picone A, Portella G, Santelli G, Vecchio G et al. 1996 Development of thyroid papillary carcinomas secondary to tissue-specific expression of the RET/PTC1 oncogene in transgenic mice. Oncogene 12 1821-1826.

Santoro M, Melillo RM, Carlomagno F, Fusco A \& Vecchio G 2002 Molecular mechanisms of RET activation in human cancer. Annals of the New York Academy of Sciences 963 116-121.

Sartor M, Schwanekamp J, Halbleib D, Mohamed I, Karyala S, Medvedovic M \& Tomlinson CR 2004 Microarray results improve significantly as hybridization approaches equilibrium. Biotechniques 36 790-796.

Schuringa JJ, Wojtachnio K, Hagens W, Vellenga E, Buys CH, Hofstra R \& Kruijer W 2001 MEN2A-RET-induced cellular transformation by activation of STAT3. Oncogene 20 5350-5358.

Shimoyama Y, Gotoh M, Terasaki T, Kitajima M \& Hirohashi S 1995 Isolation and sequence analysis of human cadherin-6 complementary DNA for the full coding sequence and its expression in human carcinoma cells. Cancer Research 55 2206-2221.

Shinohara S \& Rothstein JL 2004 Interleukin 24 is induced by the RET/PTC3 oncoprotein and is an autocrine growth factor for epithelial cells. Oncogene 23 7571-7579.

Specht MC, Tucker ON, Hocever M, Gonzalez D, Teng L \& Fahey TJ 3rd 2002 Cyclooxygenase-2 expression in thyroid nodules. Journal of Clinical Endocrinology and Metabolism 87 358-363.

Su ZZ, Madireddi MT, Lin JJ, Young CS, Kitada S, Reed JC, Goldstein NI \& Fisher PB 1998 The cancer growth suppressor gene mda-7 selectively induces apoptosis in human breast cancer cells and inhibits tumor growth in nude mice. PNAS 95 14400-14405. 
Sugg SL, Ezzat S, Rosen IB, Freeman JL \& Asa SL 1998 Distinct multiple RET/PTC gene rearrangements in multifocal papillary thyroid neoplasia. Journal of Clinical Endocrinology and Metabolism 83 4116-4122.

Tong Q, Xing S \& Jhiang SM 1997 Leucine zipper-mediated dimerization is essential for the PTC1 oncogenic activity. Journal of Biological Chemistry 272 9043-9047.

Trovato M, Grosso M, Vitarelli E, Ruggeri RM, Alesci S, Trimarchi F, Barresi G \& Benvenga S 2003 Distinctive expression of STAT3 in papillary thyroid carcinomas and a subset of follicular adenomas. Histology and Histopathology 18 393-399.

van den Elsen PJ, Holling TM, Kuipers HF \& van der Stoep N 2004 Transcriptional regulation of antigen presentation. Current Opinion in Immunology 16 67-75.

Vazquez F, Hastings G, Ortega MA, Lane TF, Oikemus S, Lombardo M \& Iruela-Arispe ML 1999 METH-1, a human ortholog of ADAMTS-1, and METH-2 are members of a new family of proteins with angioinhibitory activity. Journal of Biological Chemistry 274 23349-23357.

Viglietto G, Chiappetta G, Martinez-Tello FJ, Fukunaga FH, Tallini G, Rigopoulou D, Visconti R, Mastro A, Santoro M \& Fusco A 1995 RET/PTC oncogene activation is an early event in thyroid carcinogenesis. Oncogene 11 1207-1210.

Visconti R, Cerutti J, Battista S, Fedele M, Trapasso F, Zeki K, Miano MP, de Nigris F, Casalino L, Curcio F et al. 1997 Expression of the neoplastic phenotype by human thyroid carcinoma cell lines requires NFkappaB p65 protein expression. Oncogene 15 1987-1994.

Wang J, Knauf JA, Basu S, Puxeddu E, Kuroda H, Santoro M, Fusco A \& Fagin JA 2003 Conditional expression of RET/PTC induces a weak oncogenic drive in thyroid PCCL3 cells and inhibits thyrotropin action at multiple levels. Molecular Endocrinology 17 1425-1436.
Wang T, Niu G, Kortylewski M, Burdelya L, Shain K, Zhang S, Bhattacharya R, Gabrilovich D, Heller R, Coppola D et al. 2004 Regulation of the innate and adaptive immune responses by Stat-3 signaling in tumor cells. Nature Medicine 10 48-54.

Welch MD, DePace AH, Verma S, Iwamatsu A \& Mitchison TJ 1997 The human Arp2/3 complex is composed of evolutionarily conserved subunits and is localized to cellular regions of dynamic actin filament assembly. Journal of Cell Biology 138 375-384.

Wheeler DL, Church DM, Edgar R, Federhen S, Helmberg W, Madden TL, Pontius JU, Schuler GD, Schriml LM, Sequeira E et al. 2004 Database resources of the National Center for Biotechnology Information update. Nucleic Acids Research 32 Database issue D35-D40.

Wirtschafter A, Schmidt R, Rosen D, Kundu N, Santoro M, Fusco A, Multhaupt H, Atkins JP, Rosen MR, Keane WM et al. 1997 Expression of the RET/PTC fusion gene as a marker for papillary carcinoma in Hashimoto's thyroiditis. Laryngoscope 107 95-100.

Wolfinger RD, Gibson G, Wolfinger ED, Bennett L, Hamadeh H, Bushel P, Afshari C \& Paules RS 2001 Assessing gene significance from cDNA microarray expression data via mixed models. Journal of Computational Biology 8 625-637.

Yang YH, Dudoit S, Luu P, Lin DM, Peng V, Ngai J \& Speed TP 2002 Normalization for cDNA microarray data a robust composite method addressing single and multiple slide systematic variation. Nucleic Acids Research 30 e15.

Zannini M, Avantaggiato V, Biffali E, Arnone MI, Sato K, Pischetola M, Taylor BA, Phillips SJ, Simeone A \& Di Lauro R 1997 TTF-2, a new forkhead protein, shows a temporal expression in the developing thyroid which is consistent with a role in controlling the onset of differentiation. EMBO Journal 16 3185-3197. 